TURIZAM

Volume 20, Issue 1

12-22 (2016)

ORIGINAL

SCIENTIFIC PAPER

\title{
Attitudes of Citizens of Split and the Profession towards the Impact of Cruise Tourism on the Area of Split
}

\author{
Helena Ćosić, Srećko Favro* \\ Received: July 2015 | Accepted: December 2015
}

\begin{abstract}
Cruise tourism is a phenomenon that has rapidly developed in a very short period of time. Every year, larger and larger cruisers with the possibility to accept up to 6,000 passengers are built. Arrival of a large number of passengers and mega-ships can have a dramatic impact on the visited port, the place and the population. There are three impacts of cruise tourism: the impact on society, economic impact and environmental impact.

This form of tourism has a positive and negative impact on coastal and island tourist destinations. Economic effects are undoubtedly significant and contribute to the economic development of the region and the country. Revenues generated by this sector vary from country to country, depending on the inclusion of participants of operational and public sectors in various activities of this industry. However, negative effects on the image of the destination, on sojourns of stationary tourists, on the life of the local residents and the environment must not be ignored.

In this paper, the attention is paid to the impact of cruise tourism, and attitudes of local people and professionals towards the impact of cruise tourism on the city of Split.
\end{abstract}

Key words: cruise tourism, the impact of cruise tourism, attitudes of citizens and the profession in Split

\section{Introduction}

In the last two decades, the development of cruise tourism in the world is impressive. In 2013, the total number of passengers on cruise ships is estimated at about 21.3 million, as compared to 1995 indicates an increase in demand of about 3.5 times.

Although cruises make up less than $2 \%$ of the global tourism market, they are more and more present in the world. The demand for this specific form of tourism offer grows almost twice as fast as the number of international arrivals, and, according to forecasts, every year it will grow as the part of the world, European and Mediterranean tourism (Peručić, 2013).

Today, there are approximately 300 cruisers cruising worldwide, and their most popular destinations are the Caribbean, the Mediterranean, Alaska, Mexico, and the rest of Europe.

* University of Split, Faculty of Economics, 21000 Split, Croatia, Corresponding author: hcosic73@gmail.com 
The Adriatic Sea is also becoming an important area of interest, with the ports of Venice, Dubrovnik, Split and Bari. In the last few years, Split has a great increase in arrivals of cruisers which can cause major problems with the acceptance of ships and passengers, and can have negative impacts on the environment and on local residents.

Most of the research related to the development of cruise tourism in Europe take into account economic impact and the impact on the environment,such as: Contribution of Cruise Tourism to the Economies of Europe - annual report commissioned by the European Cruise Council (European Cruise Council, 2013), Tourist facilities in ports, Enhancing sustainable growth of cruise tourism in Europe (Policy Research Corporation, 2009), TOMAS Brodska kružna putovanja 2006. - Stavovi i potrošnja turista na brodskim kružnim putovanjima (Institut za turizam), Direct pollution cost assessment of cruising tourism in Croatian Adriatic (Caric, 2010), Čimbenici štetnog djelovanja cruising-turizma na brodski okoliš (Šantić, L. i dr., 2011), etc, while less attention is paid to the social impact of cruise tourism in the tourist destination. There are only two studies in Croatia relating to the attitudes of the local population on the cruise tourism and its future development, and those are "The attitudes of citizen of Dubrovnik towards the impact of cruise tourism on Dubrovnik"(Peručić, D., Puh, B., 2012) and a survey conducted by the Institute of Tourism in 2006 as part of the "Study of sustainable development of cruise tourism in Croatia". Both studies were conducted in Dubrovnik as a leading port of cruise tourism in Croatia.

\section{Cruise Tourism Worldwide}

Global cruise industry cruise generated revenues of 36.27 billion dollars in 2013. The number of passengers on cruisers has increased compared to the year 2012 and is expected to exceed 24 million in 2018. The average passenger on a cruise generates the revenue of 1.728 dollars, and the average income was $\$ 185$ in 2013. Cruise industry has been growing dynamically for the last 30 years, initially triggered by demand from North America, followed by the growing demand from Europe and recently from Oceania.

Table 1. International demand for cruises, 2003-2013 (Millions of passengers)

\begin{tabular}{|l|c|c|c|c|c|c|c|c|}
\hline Region & 2003 & $\mathbf{2 0 0 8}$ & $\mathbf{2 0 0 9}$ & $\mathbf{2 0 1 0}$ & $\mathbf{2 0 1 1}$ & $\mathbf{2 0 1 2}$ & $\mathbf{2 0 1 3}$ & Ten-years growth \\
\hline North America & 8.23 & 10.29 & 10.40 & 11.00 & 11.44 & 11.64 & 11.82 & $43.6 \%$ \\
\hline Europe & 2.71 & 4.47 & 5.04 & 5.67 & 6.15 & 6.23 & 6.40 & $136.2 \%$ \\
\hline Total & 10.94 & 14.76 & 15.44 & 16.67 & 17.59 & 17.87 & 18.22 & $66.5 \%$ \\
\hline The rest of the world & 1.08 & 1.54 & 2.15 & 2.40 & 2.91 & 3.03 & 3.09 & $186.1 \%$ \\
\hline Total & 12.02 & 16.30 & 17.59 & 19.07 & 20.50 & 20.90 & 21.31 & $77.3 \%$ \\
\hline
\end{tabular}

Source: CLIA (2014)The Global Economic Contribution of Cruise Tourism 2013

Table 1 indicates the international growth of the cruise sector in the period between 2003 and 2013. Since 2003, the number of passengers originating from North America has increased by $44 \%$, and the region remains the dominant source on the market. At the same time, with strong global growth appeared new emissive and receptive markets. The share of North America in the world cruise market increased by $55.5 \%$ in 2013 as new markets arose. At the same time, the share of Europe increased from $22.5 \%$ in 2003 to $30.0 \%$ in 2013, while the share of the rest of the world increased from $9.0 \%$ to $14.5 \%$ in the period of 10 years (CLIA, 2014). 
Therefore, the cruise industry is a global industry with passengers originating from all over the world and with itineraries designed for countries and ports all over the world. It is also a dynamic industry with total global growth rates higher than the mainland tourism in the past ten years. The dynamics can also be seen on the geographical distribution of growth that has been moved from North America to Europe and now Oceania (CLIA, 2014).

\section{Cruise Tourism in Croatia}

Twenty ports/destinations take part in the international cruise tourism in Croatia. Most of these ports/destinations have only symbolic and occasional traffic, visited mostly by small, luxurious vessels. The main cruise ports are Dubrovnik and Split, followed by Korčula and Zadar, which are visited by ships with more than thousand passengers.

Table 2. The number of calls to a given port and the number of passengers per city, 2007-2013

\begin{tabular}{|c|c|c|c|c|c|c|c|c|}
\hline \multirow{2}{*}{ Year } & \multicolumn{2}{|c|}{ SPLIT } & \multicolumn{2}{c|}{ DUBROVNIK } & \multicolumn{2}{c|}{ ZADAR } & \multicolumn{3}{c|}{ KORČULA } \\
\cline { 2 - 10 } & $\begin{array}{c}\text { Number of } \\
\text { calls }\end{array}$ & $\begin{array}{c}\text { Number of } \\
\text { passengers }\end{array}$ & $\begin{array}{c}\text { Number of } \\
\text { calls }\end{array}$ & $\begin{array}{c}\text { Number of } \\
\text { passengers }\end{array}$ & $\begin{array}{c}\text { Number of } \\
\text { calls }\end{array}$ & $\begin{array}{c}\text { Number of } \\
\text { passengers }\end{array}$ & $\begin{array}{c}\text { Number of } \\
\text { calls }\end{array}$ & $\begin{array}{c}\text { Number of } \\
\text { passengers }\end{array}$ \\
\hline 2007 & 185 & 99281 & 606 & 667769 & 88 & 24813 & 160 & 30000 \\
\hline 2008 & 256 & 121525 & 700 & 850828 & 97 & 24231 & 219 & 33718 \\
\hline 2009 & 232 & 131833 & 628 & 845603 & 72 & 12286 & 182 & 55786 \\
\hline 2010 & 257 & 172378 & 705 & 916089 & 80 & 17157 & 212 & 73421 \\
\hline 2011 & 252 & 181963 & 681 & 985398 & 98 & 28677 & 180 & 59666 \\
\hline 2012 & 269 & 245451 & 654 & 950791 & 57 & 20958 & 144 & 42599 \\
\hline 2013 & 225 & 189107 & 692 & 1085043 & 69 & 33647 & 151 & 24786 \\
\hline
\end{tabular}

Made by the author, source: port authority

According to the Croatian Bureau of Statistics, in the period from January to December 2013, foreign vessels realised 828 cruises in the Republic of Croatia. During these cruises, the total of $1,237.623$ passengers arrived. They stayed for 1.638 days in the Republic of Croatia, that is, 2 days on the average. The total number of passengers' sojourns in that same period was by $10.5 \%$ higher. In comparison to the same period in 2012, the number of cruises increased by $3.2 \%$, and the number of passengers entering the Republic of Croatia also increased by $7.2 \%$. In the same period, the total number of passengers' sojourns in Croatia was by $10.5 \%$ higher.

In comparison to stationary tourism, cruise tourism is characterized by considerably less expressed seasonality, both in the number of calls, and in the number of passengers by months, and the season starts earlier and ends later. Most of the traffic passes from May to October (91 $\%$ of calls and $82 \%$ of passengers).

\section{Cruise Tourism in Split}

Due to the unique historical heritage and its 1700 years of tradition, Split has become an unavoidable destination for vessels cruising across the Mediterranean. While cruising,vessels have recently started visiting the port of Split. To be more specific, vessels on cruises started arriving in 2002. That year, 82 vessels arrived to Split with 20,616 passengers and in 2013225 ships with a total of 189,107 passengers. In addition to the increased traffic, the arrival of cruisers in 
Split changes the centuries-old paradigm of Split. Split is transforming from an old transit centre and the starting point to island destinations into an attractive tourist destination. Due to a significant increase in cruise vessels arrivals and the number of passengers, the construction of docks for passenger vessels on the outer part of the breakwater of the City Port of Split is in process. Upgrading dry berths in the city port of Split, the existing capacities for the reception of large cruisers and ships in international transport will significantly increase, which will also solve the problem of traffic congestion on the existing berths, and will raise the level of service and security in the port, to ship owners, and passengers and port users as well.

\section{Impacts of Cruise Tourism}

\section{The impact of Cruise Tourism on Society}

It primarily refers to the impact of cruise on local population and stationary guests, and it arises from the presence of cruisers in the area and to the simultaneous presence of a large number of visitors from cruisers. The increased number of tourists from cruisers requires more tourist guides, sellers, bus drivers, and similar service occupations, as well as the greater involvement of the police, both in traffic and in the security of passengers as the great number of passengers attract crime. The huge influx of travellers on a limited number of hours creates the problem of crowded places where a large number of passengers occupies the same location at the same time. The spread of various gastro diseases, so-called Noro viruses, are often connected with naval cruises.

There is also an impact on the language of local residents because passengers mostly speak English. Cruises have the greatest impact on population in strict urban areas where indigenous peoples migrate due to higher cost of living. The local residents are a barometer of behaviour for passengers from cruisers. What will be the relationship between passengers and the local residents depends on their numerical proportion and different sociological characteristics.

\section{Economic Impact}

Tourist phenomenon like cruises has already been transformed into a serious socio-economic activity. Natural attractions and other available tourism resources are included and charged with the help of this kind of tourism. The tourist market of demand directly and indirectly encourages the development of many industries and businesses, with additional income for local residents and greater employment opportunities. All this causes a general increase in standards, reduced emigration, revitalization of different activities specific for a particular place, and stimulates the growth of utilities, the balance of payments of the country, the social product and national income (Perić, Oršulić, 2011).

The direct effects include production, employment and employment fee that have been achieved in European companies and suppliers who sell goods and services directly to cruise vessels, cruise passengers and crew. Expenditures related to cruise vessel include port costs, marine expenses, fuel, water, maintenance and other services. Cruise passengers expenditures include those that are related to spending while travelling, such as taxis, souvenirs, jewellery, shore excursions, food and beverages, etc. Crew expenditures are similar to the ones of passengers, even thou in a different ratio, and with a special emphasis on transport, retail goods, food and drinks. Indirect effects result from the purchases of direct suppliers like goods from other 
companies. Indirect economic revenues are related to the expenditures of goods and local services (tour operators, agencies, suppliers) that offer services to vessels on cruises. Induced revenues are proportional to direct and indirect recipients produced (Banić, 2011).

\section{Environmental Impacts}

- Cruising ships air pollutionis caused by diesel engines which noxious substances are: nitrogen oxides, sulfur oxides, carbon monoxide, hydrocarbons and carbon dioxide that affect the ambient changes, such as precipitation of acids, eutrophication and nitrification of water, creation of the haze and reduced visibility. All this contributes to the overall failure in meeting air quality standards and affects the health of local residents.

- Waste water pollution caused by wastewaters from cruisers(bilge, black and grey waters): Each passenger produces between 20 - 40 litres of black water (sewage from toilets) and 120 to 451 litres of grey water (sinks, showers, baths, washers, ship deck cleaning, swimming pools, saunas, etc.) daily. Heavy metals, bacteria and pathogenic organisms from waste waters (black and grey) are deposited on the seabed and are potential danger to humans who consume foods from living organisms from the seabed (Carić, 2010). Bilge water is a mixture of water, oil, lubricants, cleaning chemicals and other similar waste collected in the bilge, produced by main and auxiliary engines, boilers and other mechanical machines.

- Ballast water pollution: Ballast water contains liquid and solid impurities of different structure and live or dead marine organisms. Due to release of ballast from passenger ships, invasive species can be imported, and ultimately habitat can be destroyed. Marine organisms transferred by ballast water in new sea waters have no natural enemies and there is a possibility of high speed reproduction (Šantić, et al., 2011).

- Solid waste pollution. Waste from cruisers may be non-hazardous or hazardous. Non-hazardous waste consists of packaging material products used for transport and storage, waste generated from the activities of passengers and crew, and food remains. It is estimated that the amount of daily waste produced per passenger is from 2.4 to $4 \mathrm{~kg}$. Taking these figures, a week long cruise with 3000 passengers aboard generates 50.4 tonnes of waste. Hazardous waste because of its quantity, concentration, physical and chemical properties can be potentially hazardous to human health and the environment, especially if improperly treated, stored and transported. Hazardous waste generally contains hazardous substances, such as liquids, gases or solids that must be disposed separately from other wastes. It is estimated that a cruiser daily produces from 55 to 85 litres of such hazardous waste.

\section{The Empirical Survey on Attitudes of Citizens and the Profession towards the Impacts of Cruise Tourism on Split Area}

Most researches related to the development of cruise tourism in Europe take into account the economic impact and the impact on the environment, while less attention is paid to the social impact of cruise tourism on a tourist destination.

There are only two studies in Croatia related to the attitudes of citizens towards the cruise tourism and its future development, and that are "Attitudes of citizen of Dubrovnik towards the impact of cruise tourism on Dubrovnik" (Peručić, D., Puh, B. 2012) and a survey conducted by the Institute of Tourism in 2006 as part of "The study of sustainable development of cruise tourism in Croatia“. Both studies were conducted in Dubrovnik as a leading port of cruise tourism in Croatia. 


\section{Research Methodology}

This research aimed to analyse attitudes towards the impacts of cruise tourism on the city of Split. Necessary data was collected in the period from June to December 2014 and a questionnaire was used as the research instrument. The study was conducted on two groups: citizens and profession ( the Tourist Board, the Port Authority, Jadrolinija and Brodosplit ). One hundred and twenty surveys were collected from citizens and 20 from profession.

The first part of the questionnaire focuses on socio-demographic data of respondents (gender, age, education and the question about direct or indirect connection with the cruise tourism). The second part consists of a series of statements that question people's perceptions of cruise tourism and its impacts. A 5 point Linkert scale was used to measure the level of agreement with the statement. With the support of statistical data processing programme, the results were analyzed in order to accept or reject research hypotheses.

The following hypotheses were set up:

$\mathrm{H}_{1}$ : Profession and citizens have a positive attitude towards the impact of cruise tourism on the economy.

$\mathrm{H}_{2}$ :Profession and citizens have different views on the impacts of cruise tourism on society and the environment.

- $\mathrm{H}_{2 \mathrm{a}}$ : Profession and citizens have different attitudes towards the impacts of cruise tourism on societies.

- $\quad \mathrm{H}_{2 \mathrm{~b}}$ : Profession and citizens have different attitudes towards the impacts of cruise tourism on society

$\mathrm{H}_{3}$ : The historic core is not ready to receive more visitors from cruisers.

\section{Results from research}

The research included 120 citizens of the city of Split and 20 tourist employees in relation with cruising tourism. Out of 120 residents 62 were males and 58 females. The largest number of respondents was in the age group 20-29 (42 respondents), and then in the age group 40-49 that included 24 respondents. Most of them (64 respondents) had secondary education. Out of 20 respondents who were tourist employees, 9 were males and 11 females. The largest number of respondents was in the age group +50 ( 7 respondents), and then in the age group 40-49 ( 5 respondents). The largest number of them completed college and university education (6 respondents), followed by secondary education ( 5 respondents).

$\mathrm{H}_{1}$ : Profession and citizens have a positive attitude towards the impact of cruise tourism on the economy.

Mann-Whitney test indicates that there is no statistically significant difference in the attitudes of the profession and citizens on these statements, because the significance is greater than $\alpha=0.05$.

Analysing the attitudes of citizens and profession, the results have shown that $90 \%$ of respondents from tourism sector and $80,8 \%$ of citizens agree with the statement that economic benefits obtained from cruise tourism are significant. Furthermore, $95 \%$ of respondents from tourism sector and $86,6 \%$ of citizens agree with the statement that international cruise tourism has a positive impact on promotion of Split as a tourist destination. $45 \%$ of respondents from tourism sector agree that tourists from cruisers are good consumers while $30 \%$ of 
Table 3. Results of Mann-Whitney test for hypothesis $\mathrm{H}_{1}$

\begin{tabular}{|l|c|c|c|c|}
\hline & $\begin{array}{c}\text { Economic benefits } \\
\text { from cruising tourism } \\
\text { are significant }\end{array}$ & $\begin{array}{c}\text { International cruising has a } \\
\text { positive impact on promotion } \\
\text { of Split as a tourist destination }\end{array}$ & $\begin{array}{c}\text { Tourists from } \\
\text { cruisers are } \\
\text { good consumers }\end{array}$ & $\begin{array}{c}\text { Cruise industry } \\
\text { attracts investments } \\
\text { and consumption }\end{array}$ \\
\hline Mann-Whitney U & 1190,000 & 1090,000 & 1010,000 & 928,000 \\
\hline Wilcoxon W & 1400,000 & 1300,000 & 8270,000 & 1138,000 \\
\hline Z &,- 065 &,- 757 & $-1,163$ & $-1,712$ \\
\hline Asymp. Sig. (2-tailed) &, 949 &, 449 &, 245 &, 087 \\
\hline
\end{tabular}

Grouping Variable: Profession or citizens

Source: Own research, $n=140$

them disagree with that statement, and only $29,2 \%$ of citizens agree with that statement while $40 \%$ of them disagree. $55 \%$ of respondents from tourism sector and $71,3 \%$ of citizens agree with the statement that cruise tourism attracts investors and spending.

Taking into account Mann-Whitney test results and the analysis of attitudes both from profession and citizens, it can be concluded that the profession and citizens have a generally positive attitude towards the impact of cruise tourism on the economy, so the hypothesis $\mathrm{H} 1$ is accepted.

$\mathrm{H}_{2}$ :Profession and citizens have different attitudes towards the impacts of cruise tourism on society and the environment.

- $\mathrm{H}_{2 \mathrm{a}}$ : Profession and citizens have different attitudes towards the impacts of cruise tourism on societies.

Table 4. Results of Mann-Whitney test for hypothesis $\mathrm{H}_{2 a}$ Test Statistics ${ }^{a}$

\begin{tabular}{|c|c|c|c|c|c|c|c|}
\hline & $\begin{array}{l}\text { Cruise } \\
\text { tourism has } \\
\text { a negative } \\
\text { effect on } \\
\text { the air }\end{array}$ & $\begin{array}{l}\text { Huge crowds } \\
\text { in the old } \\
\text { city core } \\
\text { can have } \\
\text { negative } \\
\text { impact on } \\
\text { historical } \\
\text { monuments } \\
\text { due to the } \\
\text { excessive } \\
\text { and } \\
\text { uncontrolled } \\
\text { exploitation }\end{array}$ & $\begin{array}{l}\text { Big ships } \\
\text { deteriorate } \\
\text { the city } \\
\text { beauty }\end{array}$ & $\begin{array}{c}\text { Cruise } \\
\text { tourism has } \\
\text { a positive } \\
\text { effect on city } \\
\text { preservation } \\
\text { and } \\
\text { development } \\
\text { of natural } \\
\text { and cultural } \\
\text { notabilities }\end{array}$ & $\begin{array}{l}\text { Cruisers } \\
\text { increase } \\
\text { pollution } \\
\text { of the } \\
\text { environment } \\
\text { and the port }\end{array}$ & $\begin{array}{c}\text { Cruisers } \\
\text { increase the } \\
\text { amount of } \\
\text { waste }\end{array}$ & $\begin{array}{c}\text { Cruisers } \\
\text { deteriorate } \\
\text { ecosystem } \\
\text { (erosion of } \\
\text { the seabed } \\
\text { destruction } \\
\text { of flora and } \\
\text { fauna) }\end{array}$ \\
\hline $\begin{array}{l}\text { Mann-Whitney U } \\
\text { Wilcoxon W } \\
\text { Z } \\
\text { Asymp. Sig. } \\
\text { (2-tailed) }\end{array}$ & $\begin{array}{c}962,500 \\
1172,500 \\
-1,465 \\
, 143\end{array}$ & $\begin{array}{c}1149,000 \\
8409,000 \\
-, 314 \\
, 754\end{array}$ & $\begin{array}{c}970,500 \\
8230,500 \\
-1,429 \\
, 153\end{array}$ & $\begin{array}{c}733,000 \\
7993,000 \\
-2,851 \\
, 004\end{array}$ & $\begin{array}{c}948,000 \\
1158,000 \\
-1,527 \\
, 116\end{array}$ & $\begin{array}{c}1129,000 \\
8389,000 \\
-, 443 \\
, 658\end{array}$ & $\begin{array}{c}1137,000 \\
8397,000 \\
-, 389 \\
, 697\end{array}$ \\
\hline
\end{tabular}

Grouping Variable: Profession or citizens

Source: Author's research, $n=140$

Mann-Whitney test indicates that there is no statistically significant difference in the attitudes of the profession and citizens on these statements, because the significance is greater than $\alpha=0.05$. 
Analysing the attitudes of citizens and profession, the results have shown that $40 \%$ of profession and $35.9 \%$ of citizens disagree with the statement that cruise tourism has a negative effect on the air, while $25 \%$ of profession and $29.2 \%$ of citizens agree.

Regarding the above mentioned statement, $35 \%$ of the profession and citizens are undecided. $40 \%$ of the profession and $35 \%$ of the local residents agree with the statement that a big crowd of tourists in the old city centre can have a negative impact on historical monuments because of excessive and uncontrolled exploitation. With this statement $40 \%$ of the profession and $48.3 \%$ of citizens disagree. With the statement that big ships spoil the beauty of the city disagree $45 \%$ of the profession and $65 \%$ ofcitizens, and only $15 \%$ of the profession and $12.5 \%$ of citizens agrees with the statement.

The attitudes of the profession and citizens are divided over the statement that cruise tourism has a positive impact on the preservation of the city and the development of natural and cultural sights. $60 \%$ of the profession agrees with this statement, while $46.6 \%$ of citizensdisagree. $25 \%$ of the profession and $29.2 \%$ of the citizens don't have an opinion on the above mentioned statement. With the statement that cruisers increase pollution of the environment and the port agrees $55 \%$ of the profession and $59.1 \%$ of citizens. Also, $75 \%$ of the profession and $66.6 \%$ of citizens agree with the statement that cruisers increase the amount of waste and 70 $\%$ of the profession and $55 \%$ of citizens agree with the statement that cruisers deteriorate ecosystem.

Taking into account Mann-Whitney test results and the analysis of attitudes both from profession and citizens, it can be concluded that the profession and citizens have in general the same attitudes towards the impact of cruise tourism on the environment, so the hypothesis $\mathrm{H}_{2 \mathrm{a}}$ is rejected.

- $\mathrm{H}_{2 \mathrm{~b}}$ : Profession and citizens have different attitudes towards the impacts of cruise tourism on society

Table 5. Results of Mann-Whitney test for hypothesis $\mathrm{H}_{2 \mathrm{~b}}$ Test Statistics ${ }^{\mathrm{a}}$

\begin{tabular}{|c|c|c|c|c|c|c|c|}
\hline & $\begin{array}{l}\text { Cruise } \\
\text { tourism has } \\
\text { a negative } \\
\text { impact on } \\
\text { the life } \\
\text { quality of } \\
\text { citizenes }\end{array}$ & $\begin{array}{l}\text { Furtherincrease } \\
\text { in the number } \\
\text { of cruisers } \\
\text { will pose a } \\
\text { threat for the } \\
\text { life quality of } \\
\text { citizenes }\end{array}$ & $\begin{array}{l}\text { Cruise } \\
\text { industry } \\
\text { generates } \\
\text { employment }\end{array}$ & $\begin{array}{l}\text { Tourist } \\
\text { revenues } \\
\text { generate } \\
\text { the income } \\
\text { of the } \\
\text { citizenes }\end{array}$ & $\begin{array}{l}\text { Only a } \\
\text { minor part } \\
\text { of citizenes } \\
\text { benefits } \\
\text { the most } \\
\text { from cruise } \\
\text { industry }\end{array}$ & $\begin{array}{l}\text { Cruisers } \\
\text { change } \\
\text { tradition } \\
\text { and } \\
\text { cultural } \\
\text { values of } \\
\text { citizenes }\end{array}$ & $\begin{array}{l}\text { Cruise } \\
\text { industry } \\
\text { increases } \\
\text { living costs } \\
\text { of citizenes }\end{array}$ \\
\hline Mann-Whitney U & 1160,000 & 1041,500 & 1036,500 & 985,000 & 951,500 & 655,000 & 888,500 \\
\hline WilcoxonW & 8420,000 & 8301,500 & 1246,500 & 1195,000 & 1161,500 & 7915,000 & 8148,500 \\
\hline Z &,- 255 &,- 971 & $-1,005$ & $-1,311$ & $-1,525$ & $-3,336$ & $-1,915$ \\
\hline $\begin{array}{l}\text { Asymp.Sig. } \\
\text { (2-tailed) }\end{array}$ & ,799 &, 331 & ,315 & ,190 & ,127 &, 001 &, 056 \\
\hline
\end{tabular}

Grouping Variable: Profession or Citizens

Source: Author's research, $n=140$

Mann-Whitney test indicates that there is no statistically significant difference in the attitudes of the profession and citizens towards these statements, because the significance is greater than $\alpha=0.05$.

Analysing the attitudes of citizens and profession, the results have shown that $50 \%$ of profession and $61.6 \%$ of citizens disagree with the statement that cruise tourism has the negative impact on citizens'quality of living, while only $15 \%$ of profession and $10.8 \%$ of citizens agree. 
$40 \%$ of the profession and $53.3 \%$ of citizens disagree with the statement that the higher number of cruisers will pose a threat to the life quality of citizens, $35 \%$ of profession and $22.5 \%$ of citizens agree, while $25 \%$ of profession and $24.2 \%$ citizens are undecided. $35 \%$ of respondents employed in tourism and $54.1 \%$ of citizensexpress agreement that cruise tourism generates employment, $30 \%$ of them employed in tourism and $25 \%$ of citizens are undecided, while $25 \%$ of respondent employed in tourism and $20.9 \%$ of residents expressed disagreement.

$30 \%$ of respondents employed in tourism and $43.3 \%$ of residents agree that expenditures of tourists from cruisers generate the revenue for citizens, $40 \%$ of them employed in tourism and $30 \%$ of citizens disagree, while $30 \%$ of respondents employed in tourism and $26.7 \%$ of citizens are undecided.

To conclude, $20 \%$ of respondents employed in tourism and $53.3 \%$ of citizens agree that only a small part of citizens gets benefits the most from the business of cruise industry while $25 \%$ of them employed in tourism and $21.7 \%$ of citizens disagree and $55 \%$ of respondents employed in tourism and $25 \%$ of citizens are undecided. It can also be concluded that $60 \%$ of respondents employed in tourism and $25 \%$ of citizens agree with the statement that cruisers change tradition and cultural values of citizens, while $25 \%$ of them employed in tourism and almost one half of citizens disagree.

$35 \%$ of respondents employed in tourism and $20.9 \%$ ofcitizens agree with the statement that cruise industry increases citizens' costs of living while $30 \%$ of them employed in tourism and $55.8 \%$ of citizens disagree and $35 \%$ of respondents employed in tourism and $23.3 \%$ of citizensexpress no opinion on this statement.

Taking into account Mann-Whitney test results and the analysis of attitudes both from profession and citizens, it can be concluded that the profession and citizens have in general the same attitudes towards the impact of cruise tourism on society, so the hypothesis $\mathrm{H}_{2 \mathrm{~b}}$ is rejected.

Taking into account results of auxiliary hypotheses $\mathrm{H}_{2 \mathrm{a}}$ and $\mathrm{H}_{2 \mathrm{~b}}$, it can be concluded that hypothesis $\mathrm{H}_{2}$ is rejected.

$\mathrm{H}_{3}$ : The historic core is not ready to receive more visitors from cruisers.

In order to prove this hypothesis, the statement that the historic core is not ready to receive more visitors from cruisers was taken into account and respondents had to assess how much they agree with the statement using Likert scale of 1 to 5 ( 1 strongly disagree, 5 strongly agree)

Of 140 respondents, $17.1 \%$ strongly agreed (5) with the statement, $22.9 \%$ agreed (4) with the statement, $28.6 \%$ were undecided (3), $13.6 \%$ disagreed (2) and $17.9 \%$ strongly disagreed (1) with the statement.

In order to test the above mentioned hypothesis, One Sample $t$ - test was used, which indicated whether the statistical average score of the sample (mean) differed from the hypothetical value. The hypothetical value of the test is 4 , because it is considered that the relevant average level of agreement with the statement that The historic core is not ready to receive more visitors from cruisers is evaluated with the value agree (4) or strongly (5).

Table 6. One-Sample Statistics

\begin{tabular}{|l|c|c|c|c|}
\hline & $\mathbf{N}$ & Mean & Std. Deviation & Std. Error Mean \\
\hline $\begin{array}{l}\text { The historic core is not ready to receive } \\
\text { more visitors from cruisers. }\end{array}$ & $140 a ̊$ & 3,08 & 1,331 &, 112 \\
\hline
\end{tabular}


Table 7. One-Sample Test

\begin{tabular}{|c|c|c|c|c|c|c|}
\hline & \multicolumn{6}{|c|}{ Test Value $=4$} \\
\hline & \multirow{2}{*}{$\mathrm{t}$} & \multirow{2}{*}{$d f$} & \multirow{2}{*}{$\begin{array}{c}\text { Sig. } \\
\text { (2-tailed) }\end{array}$} & \multirow{2}{*}{$\begin{array}{c}\text { Mean } \\
\text { Difference }\end{array}$} & \multicolumn{2}{|c|}{$95 \%$ Confidence Interval of the Difference } \\
\hline & & & & & Lower & Upper \\
\hline $\begin{array}{l}\text { The historic core is not ready to } \\
\text { receive more visitors from cruisers }\end{array}$ & -8.193 & 139 & .000 & $* .921$ & -1.14 & -.70 \\
\hline
\end{tabular}

Source: Author's research, $n=140$

Empirical significance of $\mathrm{t}$ - value is $\alpha *=0.000 \%$ hence the $\alpha * 5 \%$.

The average value for the sample of respondents is 3.08 which is significantly different from the hypothetical value of 4 , which means that the average empirical value of the statement that the historic core is not ready to receive more guests from cruisers significantly differs from the hypothetical average value. Accordingly, the respondents disagree with the statement that the historic core is not ready to receive more visitors from cruisers. Due to this the hypothesis $\mathrm{H}_{3}$ is rejected.

\section{Conclusion}

The research results reveal that examinees (profession and citizens) have almost the same attitudes towards the impacts of cruise tourism on the area of Split. In general, they have a positive attitude towards the economic impact, but they are not sure what kind of consumers are guests from cruisers. There is no difference between the opinion of the profession and citizens regarding the impact on society or the environment. In their opinion, cruise tourism has no negative impact on the quality of life of citizens nor does it change their tradition or the cost of living.

They also think that the impact on the environment is mainly negative, although they do not know what the impact of cruise tourism on the air is, and if big crowds caused by the arrival of cruisers do not have a negative impact on historical monuments due to the excessive and uncontrolled exploitation. Finally, it was analysed whether the historic centre was ready to receive more visitors from cruisers, and examinees answered positively. The maximum sustainable daily reception of visitors in the destination is estimated at 10.00o-12.00o passengers, while the maximum reception of visitors at the same time is estimated at 5.00o-6.00o, that leads to the conclusion that the arrival of 3-4 cruisers at the same time with an average of 2.000-3.00o passengers, plus stationary guests, will bring to an excess of the maximum sustainable daily reception in the area.

These results can be attributed to the lack of knowledge on the impacts of cruise tourism, and in general the cruise industry. The problem lies in the lack of expertise, lack of professional staff employed in activities directly or indirectly related to cruise tourism, which then are not able to inform citizens about the advantages and disadvantages of this type of tourism. Since the area of Split, in the last few years has experienced a rapid growth in tourism in general, and cruise tourism as well, initiatives aiming at better acquaintance with tourism trends, cruise tourism and its impacts have to be boosted as well as the one aiming at finding the best ways to manage resources, all in accordance with the principles of sustainable development, and for the long-term benefit of all involved in this activity, and the benefit of the local and wider community. 


\section{References}

Benić, I. 2011.The Influence of Sea Cruises on Tourist Destination. Poslovna izvrsnost Zagreb, 2011, No. 1, 43-66. (In Croatian)

Brida, J. G., Aguire, S. Z. 2008. The Impacts of the Cruise Industry on Tourism Destinations, Sustainable Tourism as a factor of local development,Tangram Edizioni Scientifiche (Collana Simposi),110-120,

Brida, J.G., Zapata, S. 2010.Cruise tourism: economic, socio-cultural and environmental impacts. Int. J. Leisure and Tourism Marketing, 1, 3, 205-226.

Carić, H. 2010. Direct pollution cost assessment of cruising tourism in the Croatian Adriatic. Financial Theory and Practice,34 (2), 161-179.

CLIA 2014. The Global Economic Contribution of Cruise Tourism 2013. Retrieved from http:// www.cliaeurope.eu/, downloaded September 15, 2014.

Cruise statistics 2013. Retrieved from http://www.portdubrovnik.hr, downloaded January 4, 2015.

Development strategy of Croatian nautical tourism for the period 2009.-2019.Retrieved from http://www.mppi.hr, downloaded March 9, 2015.

Foreign vessels on cruise in the Republic of Croatia,January - December 2013Retrieved from www.dzs.hr, downoalded March 17, 2014.

Gračan, D., Zadel, Z. 2013.Quantitative and qualitative analysis of cruise tourism of the Republic of Croatia. Pomorski zbornik 47-48 (2013), 51-59. (In Croatian)

International cruise tourism - a fast-growing type of tourism in the world, 2013.Retrieved from www.vern.hr, downloaded December 21, 2014.

Niatu, A. L. 2007. Dosalsal, the floating ones; Exploring the socio-cultural impacts of cruise ship tourism on Port Vila, Vanathu residents, and their coping strategies, Lincoln Univeristy

Perić, T., Oršulić, M. 2011.Cruising-tourism in the Republic of Croatia Contributing to Sustainable Development, Naše more 58(5-6), 219-228. (In Croatian)

Peručić, D., Puh, B. 2012.Attitudes of citizen of Dubrovnik towards the impact of cruise tourism on Dubrovnik, Tourism and Hospitality Management, 18, 2, 213-228.

Peručić, D. 2013. Cruising-tourism: Development, strategies and key holders, University of Dubrovnik, Dubrovnik. (In Croatian)

Šantić, L. i dr. 2011.Harmful Factors of Cruise Tourism on Ship Environment, Naše more 58 (5-6), 229-243. (In Croatian)

The realization of traffic of tourists and cruise ship 2002-2013. Retrieved from http://portsplit. com/, downloaded February 8, 2014.

http://www.slobodnadalmacija.hr/Split/tabid/72/articleType/ArticleView/articleId/244856/ Default.aspx 